九州大学学術情報リポジトリ

Kyushu University Institutional Repository

\title{
The Effects of Green Manure (Sesbania rostrata) on the Growth and Yield of Rice
}

Latt, Yadana Khin

Myint, Aung Kyaw

Laboratory of Plant Nutrition, Division of Bioresource and Bioenvironmental Sciences, Graduate School, Kyushu University

\section{Yamakawa, Takeo}

Laboratory of Plant Nutrition, Division of Soil Science and Plant production, Department of Plant Resources, Faculty of Agriculture, Kyushu University

Ogata, Kazuo

Tropical Crops and Environment, Division of Bioresource and Bioenvironmental Sciences,

Department of Plant Resources, Faculty of Agriculture, Kyushu University

https://doi.org/10.5109/16109

出版情報：九州大学大学院農学研究院紀要. 54 (2)，pp.313-319，2009-10-29. Faculty of Agriculture, Kyushu University

バージョン：

権利関係 : 


\title{
The Effects of Green Manure (Sesbania rostrata) on the Growth and Yield of Rice
}

\author{
Yadana Khin LATT*, Aung Kyaw MYINT ${ }^{1}$, Takeo YAMAKAWA ${ }^{2}$ \\ and Kazuo OGATA
}

\author{
Tropical Crops and Environment, Division of Bioresource and Bioenvironmental Sciences, \\ Department of Plant Resources, Faculty of Agriculture, \\ Kyushu University, Fukuoka 812-8581, Japan \\ (Received June 23, 2009 and accepted July 13, 2009)
}

\begin{abstract}
Green manuring with an $\mathrm{N}_{2}$-fixing legume crop can meet a substantial portion of rice $\mathrm{N}$ requirement and provide organic matter to wetland rice soils to maintain soil fertility. Organic-N fertilizers in the form of flood-tolerant, leguminous, stem-nodulating Sesbania rostrata can be useful alternatives to resourcepoor rice farmers if applied as green manure. Therefore, the accumulation of fixed $\mathrm{N}$ by this green manure, their effect on the performance and yield of rice was examined. Firstly, root and/or stem nodulation, nitrogen fixation (acetylene-reducing activity), growth and $\mathrm{N}$ accumulation of $S$. rostrata as affected by inoculation site were studied in a pot experiment. The growth and $\mathrm{N}$ accumulation of $S$. rostrata in stem inoculation treatment was the highest. Therefore, stem inoculation method was used for growing $S$. rostrata to incorporate into the rice soils for the second experiment. In the second experiment, the effects of $S$. rostrata green manure application on the growth and yield of rice were studied. Green manure treatments (2 and 4 plants pot ${ }^{-1}$ ) were compared to urea treatments (40 and $80 \mathrm{~kg} \mathrm{~N} \mathrm{ha}^{-1}$ ) and no application treatment. Green manure treatments increased dry matter weight and grain weight of rice significantly over urea and no application treatments. All green manure treatments increased $\mathrm{N}$ uptake of the plant. It can be concluded that incorporation of green manure legumes can add large amount of biologically fixed $\mathrm{N}$ to rice soils. The effective utilization of biomass produced by the stem-nodulating S. rostrata could be an economically viable component of integrated nutrient management for increasing the yield components and yield of rice per unit area.
\end{abstract}

\section{INTRODUCTION}

For optimum yield, crops require a supply of mineral nutrients, the most important of which is nitrogen. The economic and environmental costs of the heavy use of chemical $\mathrm{N}$ fertilizers in agriculture are a global concern. Sustainability considerations mandate that alternatives to $\mathrm{N}$ fertilizers must be urgently sought. Biological nitrogen fixation (BNF), a microbiological process which converts atmospheric nitrogen into a plant-usable form, offers this alternative. Nitrogen-fixing systems provide an economically attractive and ecologically sound means of reducing external inputs and improving internal resources (Bohlool et al., 1992).

In recent years, conventional chemical farming practices, which substantially increased crop yields, have created numerous problems for mankind. Ground water pollution is considered a result of chemical farming practices. Adverse human and animal health effects are caused by residual and cumulative agricultural chemicals used for crop protection (Shrestha and Ladha, 1998). Excessive soil erosion caused by conventional farming systems has seriously reduced soil fertility and crop productivity. Also, higher cost of agricultural chemicals will significantly lower the net cash return to farmers. Renewed interest has recently been given to leguminous

\footnotetext{
1 Laboratory of Plant Nutrition, Division of Bioresource and Bioenvironmental Sciences, Graduate School, Kyushu University, Fukuoka 812-8581, Japan

2 Laboratory of Plant Nutrition, Division of Soil Science and Plant production, Department of Plant Resources, Faculty of Agriculture, Kyushu University, Fukuoka 812-8581, Japan

* Corresponding author (E-mail: ydnklatt@gmail.com)
}

green manure (LGM) to sustain lowland rice productivity, reduce farmers' dependence on mineral $\mathrm{N}$ fertilizers, and lower farmers' high cash input. BNF by short duration LGM crops has the potential to cover the substantial portion of the $\mathrm{N}$ required by rice (Ladha et al., 1988). Green manuring with nitrogen fixing legume crop can improve soil physical, chemical, and biological properties and consequently crop yields. Green manure has an advantage over other organic manures because it can be grown directly in the field and can be incorporated during land preparation or regular weeding operations. Furthermore, potential benefits of green manuring are reduced nitrate $\left(\mathrm{NO}_{3}^{-}\right)$leaching risk and lower fertilizer $\mathrm{N}$ requirements for succeeding crops. As a green manure, 40-60 day old Sesbania rostrata can substitute for about $50-70 \mathrm{~kg} \mathrm{~N} \mathrm{ha}^{-1}$ from $\mathrm{N}$ fertilizer for lowland rice (Kolar et al., 1993; Manguiat et al., 1992; Meelu et al., 1992). Well nodulated Sesbania plants may derive up to $90 \% \mathrm{~N}$ from fixation (Pareek et al., 1990) and therefore contribute $\mathrm{N}$ to rice. S. rostrata is a tropical legume of West Africa that can form nodules in both roots and stems (Rinaudo et al., 1988). It is recommended as a green manure in both Asia and Africa and is currently grown on about 500,000 hectares in the Delta and the Central Plain of Myanmar (Mar et al., 1995).

Because of its rapid growth, high $\mathrm{N}_{2}$ fixation potential, and tolerance for flooding, S. rostrata is a promising LGM species for lowland rice-farming systems (Pareek et al., 1990). However, little information is available on the potential of $S$. rostrata as green manure compared to the common farming system in terms of rice productivity. Numerous studies have examined growth and nitrogen fixation of legumes and the effects of green 
manure on soils and on the succeeding rice crop (Becker et al., 1990; Buresh and De Datta, 1991; Ladha et al., 1992; Singh et al., 1991), and have concluded that incorporation of green manure legumes can add large quantities of biologically fixed $\mathrm{N}$ to lowland rice cropping systems and improve the soil productivity. However, the adoption of sustainable green manure technology in tropical lowland rice farming systems has been limited in the past, and their use is currently declining. The use of LGM in rice cropping systems in Myanmar is very recent and information on optimal green manure management practices is lacking. This paper reports the results of studies on $\mathrm{N}_{2}$ fixation (acetylene-reduction activity), growth and $\mathrm{N}$ accumulation of $S$. rostrata as affected by inoculation site. The effects of $S$. rostrata as a green manure on the growth and yield of rice plants were also studied.

\section{MATERIALS AND METHODS}

\section{Experiment I}

Azorhizobium caulinodans culture and inoculant preparation

A. caulinodans ORS571T, stem nodulating rizobium was provided by Dr. Dreyfus, LSTM, France and was used as inoculants. The strain was cultured in TGYE broth medium (10 g Difcotryptone, $5 \mathrm{~g}$ glucose, $5 \mathrm{~g}$ yeast extract, $0.9 \mathrm{~g} \mathrm{CaCl}_{2} \cdot 2 \mathrm{H}_{2} 0$ and $1 \mathrm{~L}$ distilled water; Ladha et al., 1989) at $30^{\circ} \mathrm{C}$ for 3 days on a rotary shaker to a cell density of $10^{9}$ cells $\mathrm{mL}^{-1}$. For inoculating seeds and stems, the cell suspension was prepared by diluting $2 \mathrm{~mL}$ of the broth culture to $200 \mathrm{~mL}$ of $0.9 \% \mathrm{NaCl}$ solution.

\section{Plant culture and experimental treatments}

The experiment was conducted in the phytotron $\left(30{ }^{\circ} \mathrm{C}, 70 \% \mathrm{RH}\right)$ under natural daylight condition at Kyushu University, Japan from March to April in 2008. The pots were filled with $3 \mathrm{~kg}$ of soil taken from a paddy field of Kyushu University Farm. The soil was sieved through a $2 \mathrm{~mm}$ sieve, thoroughly mixed, and placed in pots which were kept flooded on 3 days before sowing.

$S$. rostrata seeds were scarified with concentrated $\mathrm{H}_{2} \mathrm{SO}_{4}$ for 30 minutes, then washed thoroughly with sterile water and germinated on moist filter paper in Petri dishes at $30{ }^{\circ} \mathrm{C}$ for 2 days. Three seeds were sown per pot and seedlings were thinned to one on 5 days after sowing (DAS). Four treatments were included in this experiment: (1) Seed inoculation; (2) Stem inoculation; (3) Seed and stem inoculation; and (4) No inoculation. For seed inoculation treatment, seeds were inoculated by applying $5 \mathrm{~mL}$ cell suspension on each seed at sowing. At the same time, each seed was applied by $5 \mathrm{~mL}$ of $\mathrm{NaCl}$ solution for stem and no inoculation treatments. Stems will be inoculated by spraying cell suspension (cell density: $10^{7}$ cells $\mathrm{mL}^{-1}$ ) on the aerial portion of each plant on 30 DAS. Pots in each experiment were arranged in a completely randomized block design with three replications. The BNF ability was estimated by using acetylene reduction assay.
Determination of acetylene-reducing activity (ARA), dry weight, nodule number and nitrogen accumulation

Sixty days after sowing, the plant of each treatment was uprooted and carefully washed off the soil. The plant roots were removed at about $2-3 \mathrm{~cm}$ above the crown and the aerial stem was cut into 4 pieces (about $15 \mathrm{~cm}$ each). The root and stem portions of plant from each pot were separately placed in $500 \mathrm{~mL}$ glass bottles into which $50 \mathrm{~mL}$ of acetylene gas was changed. Gas samples of $1 \mathrm{~mL}$ were withdrawn after 5 and 64 minutes from the exposure to acetylene and the amount of ethylene was determined using a gas chromatograph (GC-14A, Shimazu, Kyoto, Japan) according to the method of Sarr et al. (2009).

After measuring acetylene-reducing activity, the numbers of nodules were counted and the leaf, stem, root and nodule dry weight were measured for each plant after oven-drying at $70{ }^{\circ} \mathrm{C}$ for $48 \mathrm{~h}$. The leaf, stem, root and nodule samples were separately ground to fine powder by using grinding mill (Cyclotec 1093, Foss Analytical AB, Sweden). And then the digestion of the ground samples was done by salicyclic- $\mathrm{H}_{2} \mathrm{SO}_{4}-\mathrm{H}_{2} \mathrm{O}_{2}$ digestion method (modified Kjeldahl digestion method) stated by Ohyama et al. (1991). The digests were determined for total nitrogen by using indophenols method as described in Cataldo et al. (1974), for total phosphorus by ascorbic acid method (Murphy and Riley, 1962) and for total potassium by atomic absorption spectrophotometer (Z-5300, Hitachi, Japan).

\section{Experiment II \\ Green manure production}

Soil and plant material

Pot experiment was conducted in the phytotron $\left(25^{\circ} \mathrm{C}, 70 \% \mathrm{RH}\right)$ under natural daylight condition at Kyushu University, Japan from May to June 2008. The soil used for this experiment had the background history of fertilization with organic manure (cow and poultry manure) in the previous years. S. rostrata was used as a green manure in the experiment. Seeds were scarified for 30 minutes in concentrated $\mathrm{H}_{2} \mathrm{SO}_{4}$, then washed thoroughly with sterile water and germinated on moist filter paper in Petri dishes at $30^{\circ} \mathrm{C}$ for 2 days and transplanted in the pots mentioned above.

\section{Green manure culture and incorporation}

Four treatments were included in the study; (1) CGM-1: Sesbania level I (2 plants grown in soil applied with cow manure in the previous year); (2) CGM-2: Sesbania level II (4 plants grown in soil applied with cow manure in the previous year); (3) PGM-1: Sesbania level I (2 plants grown in soil applied with poultry manure in the previous year); and (4) PGM-2: Sesbania level II (4 plants grown in soil applied with poultry manure in the previous year. The pots of all treatments were arranged in a completely randomized block design with three replications. For green manure level I or II treatments, twelve or six scarified seeds of $S$. rostrata were sown, and the plants were thinned to two or four per 
pot, respectively on 5 days after planting. No chemical fertilizer was applied to the green manure treatments for evaluating the actual effects of the green manure on the growth and yield of rice. A. caulinodans culture and inoculant preparation were done as described in experiment I. Two times of stem inoculation were done by spraying cell suspension (cell density: $10^{7}$ cells $\mathrm{mL}^{-1}$ ) on the aerial portion of each plant at 20 and 30 DAS. Sixty days after sowing, the subsamples were taken from each treatment to determine the plant dry weight, N, P and K accumulation and the remaining plant parts were cut into small pieces and mixed thoroughly with the roots. And then the shoot and root pieces were divided into three portions, weighed equally and incorporated into each replicated pot for the next rice experiment on 5 days before transplanting rice.

\section{Rice production}

\section{Treatment design and cultivation}

Pot experiment was conducted in a net-house under natural environmental condition during 2008 (from July to November). Nine treatments were laid out in a completely randomized block design with three replications. (1) C-cont.: Previous cow manure soil with no application; (2) CGM-I: Previous cow manure soil incorporated with 2 plants of Sesbania (level I); (3) CGM-II: Previous cow manure soil incorporated with 4 plants of Sesbania (level II); (4) P-cont.: Previous poultry manure soil with no application; (5) PGM-I: Previous poultry manure soil incorporated with 2 plants of Sesbania (level I); (6) PGM-II: Previous poultry manure soil incorporated with 4 plants of Sesbania (level II); (7) Low-U: Low rate of urea (40 $\mathrm{kg} \mathrm{N} \mathrm{ha}^{-1}$ ) with previous low chemical fertilizer application; (8) High-U: High rate of urea (80 $\mathrm{kg} \mathrm{N} \mathrm{ha}^{-1}$ ) with previous complete fertilizer application; and (9) NA: No application.

One 21-day old seedling of rice was transplanted into each pot at 5 days after incorporation of green manure. Rice (Oryza sativa L.) variety Manawthukha (Myanmar high yielding variety) was used in the study. In urea treatments, three equal splits were done at basal, tillering and panicle initiation. Total N, P and K amount from applied $S$. rostrata and urea were shown in Table 1. Tap water was used for irrigation. The water level in the pot was kept at 3-5 cm depth above the soil surface until 2 weeks before harvest. Pesticides were applied as needed. Excluding 21 days in the seedbed, the rice plants were grown for an average of 135 days.

\section{Plant sampling and analysis}

During the cultivation period, the plant growth characteristics; plant height, tiller number and SPAD value were measured weekly until panicle initiation. At physiological maturity, the rice plants were cut at $2-3 \mathrm{~cm}$ above ground level. Dry weight of straw and grain, and yield components were determined. Grain yield was determined at 14\% moisture content after air-dried. Straw dry weight was analyzed after oven-drying to get constant weight at $70{ }^{\circ} \mathrm{C}$ for 2 days. Dried grain and straw samples were ground and digested by $\mathrm{H}_{2} \mathrm{SO}_{4}-\mathrm{H}_{2} \mathrm{O}_{2}$ digestion method (modified Kjeldahl digestion method) stated by Ohyama et al. (1991). The total N, P and K were determined by the methods as described above.

\section{Statistical analysis}

For statistical analysis, one-way ANOVA for the

Table 1. Amount of total N, P and K from applied S. rostrata and urea

\begin{tabular}{|c|c|c|c|c|c|c|}
\hline \multirow{2}{*}{ Treatment } & \multicolumn{2}{|c|}{ Sesbania } & \multirow{2}{*}{$\begin{array}{c}\text { Urea } \\
\left(\mathrm{g} \mathrm{pot}^{-1}\right)\end{array}$} & \multicolumn{3}{|c|}{$\begin{array}{l}\text { Total applied amount from } \\
\text { Sesbania and urea }\end{array}$} \\
\hline & Level & $\begin{array}{l}\text { Fresh wt. } \\
\left(\mathrm{g} \mathrm{pot}^{-1}\right)\end{array}$ & & $\mathrm{N}$ & $\begin{array}{c}\mathrm{P} \\
\left(\mathrm{mg} \mathrm{pot}^{-1}\right)\end{array}$ & K \\
\hline C-cont. & - & - & - & - & - & - \\
\hline CGM- I & 2 plants & 57.7 & - & 587 & 34.8 & 479 \\
\hline CGM-II & 4 plants & 61.6 & - & 590 & 32.8 & 511 \\
\hline P-cont. & - & - & - & - & - & - \\
\hline PGM-I & 2 plants & 50.9 & - & 475 & 32.8 & 473 \\
\hline PGM-II & 4 plants & 64.3 & - & 741 & 47.3 & 663 \\
\hline High-U & - & - & 0.350 & 160 & - & - \\
\hline Low-U & - & - & 0.175 & 80 & - & - \\
\hline NA & - & - & - & - & - & - \\
\hline
\end{tabular}

C-cont.: Previous cow manure soil, CGM-I: Previous cow manure soil with Sesbania level I, CGM-II: Previous cow manure soil with Sesbania level II, P-cont.: Previous poultry manure soil, PGM-I: Previous poultry manure soil with Sesbania level I, PGM-II: Previous poultry manure soil with Sesbania level II, Low- U: Low rate of urea (40 $\mathrm{kg} \mathrm{N} \mathrm{ha}^{-1}$ ) with previous low chemical fertilizer application, High-U: High rate of urea $\left(80 \mathrm{~kg} \mathrm{~N} \mathrm{ha}^{-1}\right)$ with previous complete fertilizer application, NA: No application. Sesbania were incorporated in fresh weight basis. Urea fertilizer was applied three times of split application, at basal, tillering and panicle initiation stage. 
analysis of variance to test the statistical significance and Tukey-Kramer HSD (Honestly Significant Difference) test to calculate the Least Signigicant Difference (LSD) for comparing means at 5\% probability level were conducted using software JMP (JMP IN, Version 5.1.2., SAS Institute Inc., Cary, NC, USA).

\section{RESULTS AND DISCUSSIONS}

\section{Effect on Plant biomass, nodulation and nitrogen fixation of different inoculation treatments}

Biomass production and $\mathrm{N}$ accumulation are often taken into account when predicting the usefulness of a legume for green manuring (Yoshida and Kitou, 1995). Goel et al. (1999) reported that the inoculation with certain plant growth-promoting rhizobacteria (PGPR) may enhance crop productivity by making the other nutrients available. The influence of inoculation site on plant dry weight and $\mathrm{N}$ accumulation of $S$. rostrata was shown in Table 2 and 3. Plant dry weight and nitrogenase activity showed similar trend. Stem inoculation had a highly significant effect on $\mathrm{N}$ accumulation and a significant influence on plant dry weight compared to other treatments. Stem inoculation treatment also accumulated significantly higher $\mathrm{N}$ compared to other treatments. It can be seen that dry matter production and $\mathrm{N}$ accumulation by $S$. rostrata were significantly correlated with the quantity of ARA. The results suggested that stem inoculation with $A$. caulinodans is able to increase $\mathrm{N}$ accumulation, nitrogen fixation and growth of legumes. It is evident from these results that stem inoculation of $S$. rostrata is needed in order to produce a high biomass and accumulate a large amount of $\mathrm{N}$.

Data on nodule numbers and dry weights are shown in Table 2. The means of the total number of root and stem nodules were 95, 141, 81 and 76 nodules plant ${ }^{-1}$ for seed inoculation only, stem inoculation only, both seed and stem inoculation and no inoculation treatments, respectively. Although the differences of nodule number and nodule dry weight in all treatments were not statistically significant, the mean values of nodule number and nodule dry weight in the seed inoculation treatment were generally high. As that reason, it is thought that seed
Table 3. Effects of A. caulinodans inoculation on N, P and $\mathrm{K}$ accumulation of $S$. rostrata on 60 DAS

\begin{tabular}{lccc}
\hline Treatment & $\begin{array}{c}\mathrm{N} \\
\left(\mathrm{mg} \mathrm{plant} \mathrm{H}^{-1}\right)\end{array}$ & $\begin{array}{c}\mathrm{P} \\
\left(\mathrm{mg} \mathrm{plant}^{-1}\right)\end{array}$ & $\begin{array}{c}\mathrm{K} \\
\left(\mathrm{mg} \mathrm{plant}^{-1}\right)\end{array}$ \\
\hline $\begin{array}{l}\text { Seed inoculation } \\
\text { Stem inoculation }\end{array}$ & $140.96 \mathrm{ab}$ & $16.36 \mathrm{a}$ & $131.45 \mathrm{ab}$ \\
$\begin{array}{l}\text { Seed and stem } \\
\text { inoculation }\end{array}$ & $97.51 \mathrm{~b}$ & $10.61 \mathrm{a}$ & $163.68 \mathrm{a}$ \\
$\begin{array}{l}\text { No inoculation } \\
\text { T8.64 b }\end{array}$ & $10.78 \mathrm{a}$ & $89.32 \mathrm{~b}$ \\
\hline
\end{tabular}

The same letters within columns are not significantly different using Tukey-Kramer HSD test $(P<0.05)$.

inoculation was effective for $A$. caulinodans to initiate the nodulation on root of $S$. rostrata, forming a large number of nodules in early time, increasing the size of nodules. However, in this situation, an abundant $\mathrm{N}$ was required for the formation of nodule and furthermore, the initial growth of host plant was depress and the dry matter accumulation was decreased as described below.

It was found that nitrogenase activity (ARA) increased significantly in stem inoculation treatment. Stem inoculation is generally recommended to optimize $\mathrm{N}_{2}$ fixation in $S$. rostrata. The high nitrogen fixing potential of $S$. rostrata is probably directly associated with the profuse stem nodulation (Dreyfus, 1982). $S$. rostrata developed nitrogen fixing nodules on the stem after spraying the plants with the bacterial culture of $A$. caulinodans strain ORS571T. Root nodules were also observed, and they were very small and might be loweffective for contributing $\mathrm{N}_{2}$ fixation. It was observed that only stem inoculation treatment increased nitrogenase activity (ARA) significantly although nodule number and nodule dry weight were not significantly different in all treatments. Although seed inoculation, and both seed and stem inoculation treatments resulted in greater $\mathrm{N}_{2}$ fixation than no inoculation treatment, the difference of $\mathrm{N}_{2}$ fixation was no significant statistically. It was surprisingly observed that root and stem nodules were found in no inoculation treatment. It might be due to the presence of indigenous Azorhizobium species in the soil.

Table 2. Effects of A. caulinodans inoculation on nodulation, total plant dry weight and ARA of S. rostrata on 60 DAS

\begin{tabular}{|c|c|c|c|c|c|c|}
\hline Treatment & $\begin{array}{l}\text { Root nodules } \\
\text { plant }^{-1}\end{array}$ & $\begin{array}{c}\text { Stem nodules } \\
\text { plant }^{-1}\end{array}$ & $\begin{array}{l}\text { Total nodules } \\
\text { number plant }{ }^{-1}\end{array}$ & $\begin{array}{c}\text { Dry weight of } \\
\text { nodules } \\
\left.\text { (g plant }^{-1}\right)\end{array}$ & $\begin{array}{l}\text { Total plant } \\
\text { dry weight } \\
\left(\text { g plant }^{-1}\right)\end{array}$ & $\begin{array}{c}\text { ARA } \\
\left(\mu \mathrm{mol} \mathrm{C}_{2} \mathrm{H}_{4} \mathrm{~g}^{-1}\right. \\
\text { nodule dry } \\
\left.\text { weight } \mathrm{hr}^{-1}\right)\end{array}$ \\
\hline $\begin{array}{l}\text { Seed } \\
\text { inoculation }\end{array}$ & $73 \mathrm{a}$ & $22 \mathrm{a}$ & $95 \mathrm{a}$ & $0.25 \mathrm{a}$ & $4.79 \mathrm{ab}$ & $12.74 \mathrm{ab}$ \\
\hline $\begin{array}{l}\text { Seed and stem } \\
\text { inoculation }\end{array}$ & $63 \mathrm{a}$ & $18 \mathrm{a}$ & $81 \mathrm{a}$ & $0.19 \mathrm{a}$ & $3.31 \mathrm{~b}$ & $12.64 \mathrm{~b}$ \\
\hline No inoculation & $51 \mathrm{a}$ & $25 \mathrm{a}$ & $76 \mathrm{a}$ & $0.22 \mathrm{a}$ & $3.24 \mathrm{~b}$ & $4.35 \mathrm{~b}$ \\
\hline
\end{tabular}

The same letters within columns are not significantly different using Tukey-Kramer HSD test $(P<0.05)$. 


\section{Nutrient application from incorporated green manure}

Symbiotic $\mathrm{N}_{2}$ fixation by leguminous green manure crops can provide a substantial quantity of fresh biomass which may be effectively used for organic manuring. N, $\mathrm{P}$ and $\mathrm{K}$ amount estimated from the fresh weight of incorporated $S$. rostrata was shown in Table 1. The incorporation of 57.7, 61.6, 50.9 and $64.3 \mathrm{~g} \mathrm{pot}^{-1}$ (fresh weight) of $S$. rostrata provided 586.68, 589.77, 474.46 and $740.80 \mathrm{mg} \mathrm{N}$ pot $^{-1}$ to the soil for treatment CGM-I, CGM-II, PGM-I and PGM-II, respectively. The use of $S$. rostrata as green manure provided a substantial portion of $\mathrm{N}$ requirements for rice. Nutrient accumulation in Sesbania was primarily a function of the growing period available for biomass production. Conceivably, increasing plant density will increase $\mathrm{N}$ accumulation in the plant population (Herrera et al., 1997). In this experiment, it was found that the harvested amount from green manure was not significantly different even if 2 or 4 plants were grown. It might probably be due to certain limitation of root volume in pot experiment and no limitation of light for photosynthesis. However, it was found that nutrient accumulation was significantly different although the harvested amount from green manure was not different (Table 1).

\section{Dry matter accumulation and grain yield of rice}

The response of rice to green manure and urea application is shown in Table 4 . In all green manure treatments, plant height and tiller number of Manawthukha were significantly higher than those in the urea and no application treatments. Such improvement (tiller number, number of panicles and yield) due to the beneficial effect of green manure addition has also been reported by Singh et al. (1990). Maximum dry matter weight (34.45 g pot $^{-1}$ ) was observed in PGM-II which was statistically similar to CGM-II, PGM-I and CGM-I (33.93, 31.41 and $30.87 \mathrm{~g} \mathrm{pot}^{-1}$ ). The increase in dry matter weight by $S$. rostrata application has also been reported by Azam, (1990), Rees et al. (1993), and Manguiat et al. (1997).
Lowest dry matter weight $\left(8.33 \mathrm{~g} \mathrm{pot}^{-1}\right)$ was noted in NA. It was observed that all maximum dry matter weights were from green manure treatments and the differences between levels ( 2 and 4 plants pot ${ }^{-1}$ ) of application were not significant. Because, their growth might be limited by the restricted supply of essential nutrients under pot experiment. Incorporation of $S$. rostrata enhanced the dry matter weight significantly as compared to urea application and NA treatments (Fig. 1). In green manure and urea treatments, the dry matter yield was proportional to the level of $\mathrm{N}$ applied (Fig. 2).

Similar trend as dry matter weight was observed in grain yield. All green manure treatments (CGM-II, PGM-I, CGM-I and PGM-II) produced 17.04, 15.41, 14.86 and $13.68 \mathrm{~g}$ grain yield pot $^{-1}$, respectively and all green manure treatments were not significant with each other statistically. Green manures contribute significantly to the $\mathrm{N}$ nutrition of rice. The increase in grain yield with the use of $S$. rostrata had also been observed by Beri and Meelu (1981) and Mian and Stewart (1985).

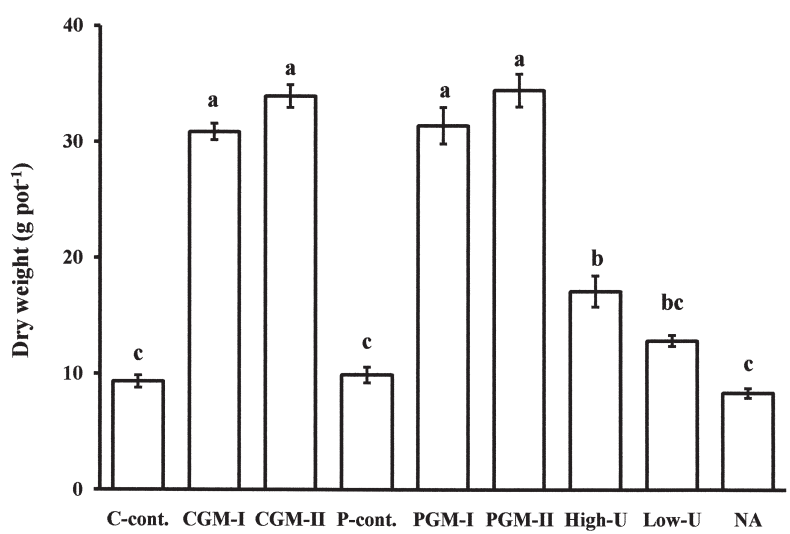

Fig. 1. Effects of $S$. rostrata and urea application on dry matter yield of rice.

The abbreviations of the treatments (C-cont., CGM-I, CGM-II, P-cont., PGM-I, PGM-II, High-U, Low-U and NA) in Fig. 1, 2, 3, 4 and 5 are the same as described in under Table 1 . The same letters indicate not significantly different using Tukey-Kramer HSD (Honestly Significant Difference) test $(P<0.05)$ in Fig. 1, 3, 4 and 5 .

Table 4. Yield components, grain yield and nutrient accumulation of rice as affected by incorporation of $S$. rostrata and urea

\begin{tabular}{|c|c|c|c|c|c|c|c|}
\hline \multirow[t]{2}{*}{ Treatment } & \multirow{2}{*}{$\begin{array}{l}\text { Plant height } \\
(\mathrm{cm})\end{array}$} & \multirow{2}{*}{$\begin{array}{c}\text { Panicles } \\
\left(\text { no. }^{\text {plant }}{ }^{-1}\right)\end{array}$} & \multirow{2}{*}{$\begin{array}{l}\text { Total dry } \\
\text { weight } \\
\left(\text { g plant }^{-1}\right)\end{array}$} & \multirow{2}{*}{$\begin{array}{l}\text { Grain weight } \\
\left(\text { g plant }^{-1}\right)\end{array}$} & \multicolumn{3}{|c|}{$\begin{array}{l}\text { Total accumulation } \\
\qquad\left(\mathrm{mg} \mathrm{plant}^{-1}\right)\end{array}$} \\
\hline & & & & & $\mathrm{N}$ & $\mathrm{P}$ & $\mathrm{K}$ \\
\hline C-cont. & 51 & 8 & $9.31 \mathrm{c}$ & $2.66 \mathrm{~b}$ & $71.26 \mathrm{~d}$ & $22.33 \mathrm{~d}$ & $151.15 \mathrm{c}$ \\
\hline CGM-I & 67 & 21 & $30.87 \mathrm{a}$ & $14.86 \mathrm{a}$ & $281.26 \mathrm{~b}$ & $64.81 \mathrm{abcd}$ & $383.01 \mathrm{~b}$ \\
\hline CGM-II & 68 & 23 & $33.93 \mathrm{a}$ & $17.04 \mathrm{a}$ & $288.73 \mathrm{~b}$ & $87.08 \mathrm{ab}$ & $538.97 \mathrm{a}$ \\
\hline $\mathrm{P}-$ cont. & 52 & 8 & $9.88 \mathrm{c}$ & $2.40 \mathrm{~b}$ & $80.71 \mathrm{~cd}$ & $19.60 \mathrm{~d}$ & $159.56 \mathrm{c}$ \\
\hline PGM-I & 69 & 22 & $31.42 \mathrm{a}$ & $15.41 \mathrm{a}$ & $314.95 \mathrm{ab}$ & $102.16 \mathrm{a}$ & $561.90 \mathrm{a}$ \\
\hline PGM-II & 69 & 23 & $34.45 \mathrm{a}$ & $13.68 \mathrm{a}$ & $356.03 \mathrm{a}$ & $75.47 \mathrm{abc}$ & $605.43 \mathrm{a}$ \\
\hline High-U & 56 & 13 & $17.1 \mathrm{~b}$ & $5.32 \mathrm{~b}$ & $134.21 \mathrm{c}$ & $36.40 \mathrm{bcd}$ & $230.46 \mathrm{c}$ \\
\hline Low-U & 56 & 11 & $12.85 \mathrm{bc}$ & $6.09 \mathrm{~b}$ & $124.95 \mathrm{~cd}$ & $32.23 \mathrm{~cd}$ & $182.88 \mathrm{c}$ \\
\hline NA & 54 & 8 & $8.33 \mathrm{c}$ & $3.56 \mathrm{~b}$ & $86.4 \mathrm{~cd}$ & $21.97 \mathrm{~d}$ & $131.17 \mathrm{c}$ \\
\hline
\end{tabular}

The same letters indicate not significantly different using Tukey-Kramer HSD (Honestly Significant Difference) test $(P<0.05)$. 


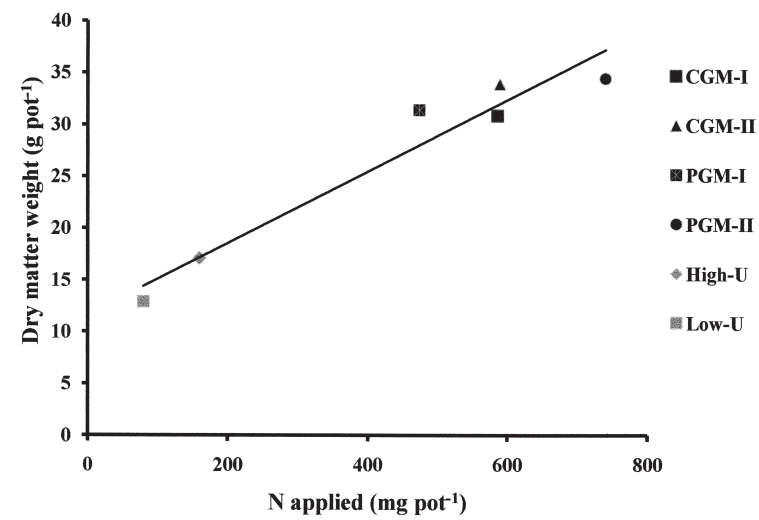

Fig. 2. Relationship between $N$ applied and dry matter yield.

\section{$\mathbf{N}, \mathbf{P}$ and $\mathrm{K}$ accumulation in rice plants}

The highest accumulation of total $\mathrm{N}$ was observed in green manure treatments. CGM-I and CGM-II increased rice plant's N uptake by $295 \%$ and $305 \%$ as compared to C-cont. and PGM-I and PGM-II increased 290\% and $341 \%$ as compared to $\mathrm{P}-$ cont., respectively, in previous cow manure and poultry manure soil. Amounts of $\mathrm{N}$ accumulation were $71.26,281.26$ and $288.73 \mathrm{mg} \mathrm{N}$ plant $^{-1}$ for C-cont., CGM-I and CGM-II, and 80.71, 314.95 and $356.03 \mathrm{mg} \mathrm{N}$ plant $^{-1}$ for P-cont., PGM-I and PGM-II, respectively. As compared to NA treatment, green

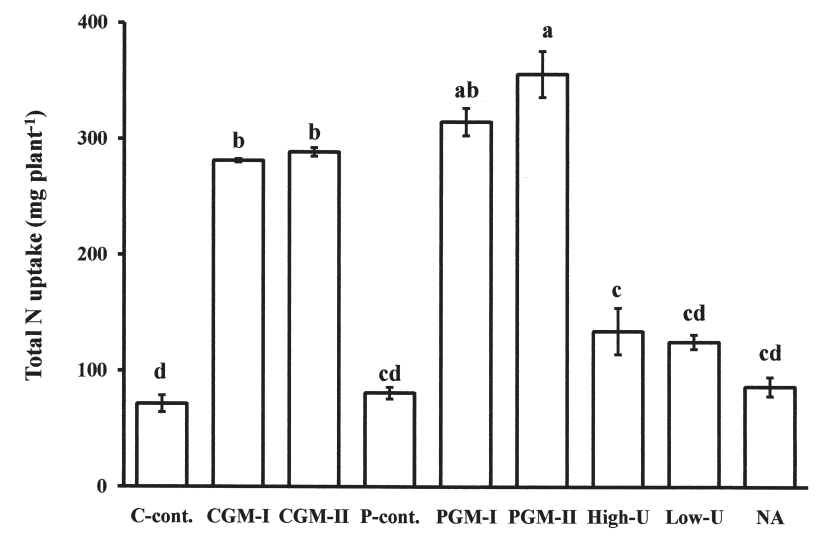

Fig. 3. Effects of $S$. rostrata and urea application on nitrogen accumulation in rice plant.

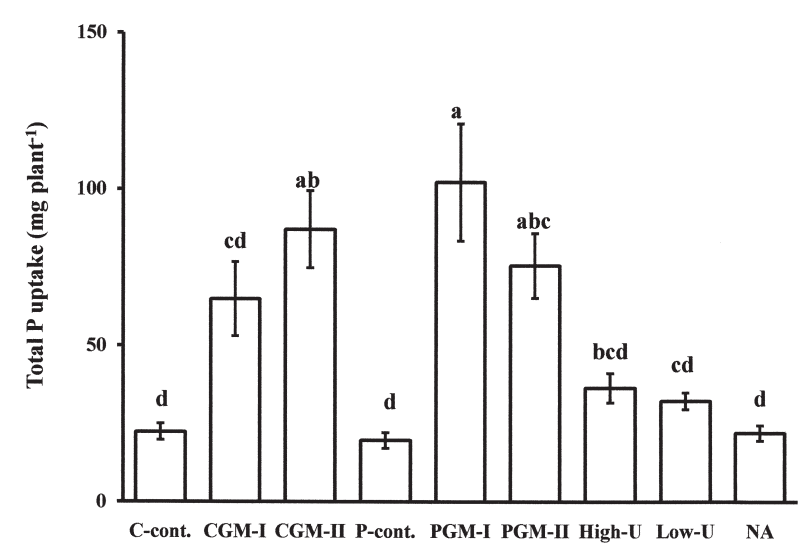

Fig. 4. Effects of $S$. rostrata and urea application on phosphorus accumulation in rice plant.

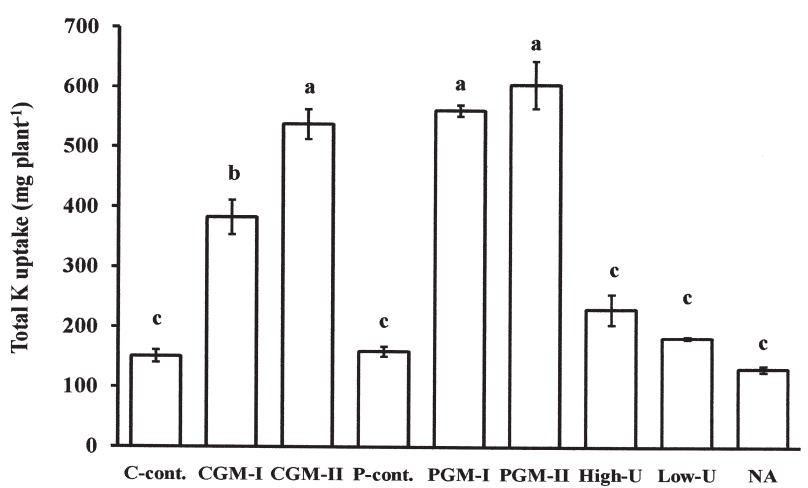

Fig. 5. Effects of $S$. rostrata and urea application on potassium accumulation in rice plant

manure level 1 and 2 treatments increased rice plant's $\mathrm{N}$ uptake by $226 \%$ and 234\% for CGM-I and CGM-II, and $265 \%$ and $312 \%$ for PGM-I and PGM-II, respectively (Fig. 3). The increasing of $\mathrm{N}$ accumulation in green manure treatments was because of the increase of added $\mathrm{N}$, but those in the urea application and NA treatments did not show an increasing tendency. It might be due to the fact that the application of $\mathrm{N}$ in green manure treatments was higher than that of urea (Table 1).

It was observed that phosphorus accumulation of rice plants in green manure treatments remained nonsignificant with urea application and NA treatments statistically (Fig. 4). The pattern of $\mathrm{K}$ accumulation was relatively similar to that of $\mathrm{N}$ (Fig. 3 and 5). The results in Fig. 5 showed that the accumulation of $\mathrm{K}$ in rice plants was significantly increased by incorporation of green manure. Amounts of $\mathrm{K}$ accumulation were 605.43, 561.9,

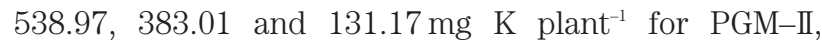
PGM-I, CGM-II, CGM-I and NA, respectively. It can be suggested that the total $\mathrm{K}$ accumulation in rice plant was increased in proportion to the increase in total $\mathrm{N}$ accumulation due to the high nitrogen fixation activity. The results indicated that the incorporation of green manure increased the $\mathrm{N}$ and $\mathrm{K}$ accumulation of rice plants and enhanced their yield.

\section{CONCLUSION}

As a conclusion from the present study results, stem inoculation method is supposed to be the best for growing $S$. rostrata to incorporate into rice soils. It can be stated that green manure treatments recorded maximum $\mathrm{N}$ uptake, and increased the yield components and yield of rice plants as compared to urea application and NA treatments due to its high application of $\mathrm{N}$ to the succeeding rice crops. Although green manure treated plants showed significant effects on yield parameters, dry matter weight, grain yield and nutrient accumulation, the differences between two levels (2 plants and 4 plants pot $^{-1}$ ) were not statistically significant. Therefore, field experiment for further investigation of effectiveness of $S$. rostrata on rice production is needed to know the appropriate level of application. 


\section{REFERENCES}

Azam, F. 1990 Comparative effects of organic and inorganic nitrogen sources applied to a flooded soil on rice yield and availability of N. Plant Soil, 125: 255-262

Becker, M. 1990 Potential use of the stem-nodulating legumes Sesbania rostrata and Aeschynomene afraspera as green manure for lowland rice (Oryza sativa L.). Ph.D. Thesis, University of Giessen, Germany

Beri, V. and O. P. Meelu 1981 Substitution of nitrogen through green manure in rice. Indian Farming, 31: 3-4

Bohlool, B. B., J. K. Ladha, D. P. Garrity and T. Georg 1992 Biological nitrogen fixation for sustainable agriculture: A perspective. Plant Soil, 141: 1-11

Buresh, R. J. and S. K. De Datta 1991 Nitrogen dynamics and management of rice-legume cropping systems. Adv. Agron. 45: $1-59$

Cataldo, D. A., L. E. Schrader and V. L. Youngs 1974 Analysis by digestion and colorimetric assay of total nitrogen in plant tissues high in nitrate. Crop Science, 14: 854-856

Dreyfus, B. L. 1982 La symbiose entre Rhizobium et Sesbania rostrata, une legumineuse a nodules caulinaires. $\mathrm{Ph} \mathrm{D}$ thesis, University of Paris

Goel, A. K., R. D. Laura, D. V. Pathak, G. Anuradhaand and A. Goel 1999 Use of biofertilizers: potential, constraints and future strategies review. Inter. J. Trop. Agric., 17: 1-18

Herrera, W. T., D. P. Garrity and C. Vejpas 1997 Management of Sesbania rostrata green manure crops grown prior to rainfed lowland rice on sandy soils. Field Crops Research, $\mathbf{4 9}$ : $259-268$

Kolar, S. J., S. H. Grewal and B. Singh 1993 Nitrogen substitution and higher productivity of rice-wheat cropping systems through green manuring. Trop. Agric., 70: 301-304

Ladha, J. K., I. Watanabe and S. Saono 1988 Nitrogen fixation by leguminous green manure and practices for its enhancement in tropical lowland rice. In Sustainable Agriculture. Green Manure in Rice Farming. pp. 165-183. International Rice Research Institute, Manila, Philippines

Ladha, J. K., Pareek, R. P. and Becker, M. 1992. Stemnodulating legume- Rhizobium symbiosis and its agronomic use in lowland rice. Adv. Soil Sci., 20: 147-192

Manguiat, I. J., D. F. Guinto, A. S. Perez and R. M. Pintor 1992 Response of rainfed lowland rice to green manuring with $S$. rostrata. Trop. Agric., 69: 73-77

Manguiat, I. J., P. W. Singleton, P. M. Rocamora, M. U. Calo and E. E. Taleon 1997 Effectiveness of Sesbania rostrata and Phaseolus calcaratus as green manure for upland rice grown in acidic soil. Plant Soil, 192: 321-331

Mar, M., T. Saing, T. Thein and R. K. Palls 1995 Sesbania green manure program for rice farming in Myanmar. In
Proceedings of the International Rice Research Conference, 21-25 April 1992. The International Rice Research Institute, Los Baños, Philippines

Meelu, O. P., R. A. Morris, R. E. Furoc and M. A. Dizon 1992 Yield responses of rice to eight tropical green manures. Trop. Agric., 69: 133-136

Mian, M. H. and W. D. P. Stewart 1985 Fate of fertilizer nitrogen applied as Azolla and blue green algae (Cyanobacteria) in waterlogged rice soils $-{ }^{15} \mathrm{~N}$ tracer study. Plant Soil, $\mathbf{8 3}$ 363-370

Murphy, J. and J. Riley 1962 A modified single solution for the determination of phosphate in natural water, Anal. Chim. Acta., 27: 31

Ohyama, T., Ito, M., Kobayashi, K., Araki, S., Yasuyoshi, S., Sasaki, O., Yamazaki, T., Soyama, K., Tanemura, R., Mizuno, Y., and Ikarashi, T. 1991: Analytical procedures of N, P, K contents in plant and manure materials using $\mathrm{H}_{2} \mathrm{SO}_{4}-\mathrm{H}_{2} \mathrm{O}_{2}$ Kjeldah. digestion method (In Japanese with English summary). Jpn. Bulletin of the Faculty of Agriculture, Nigata University, 43: 110-120 (in Japanese with English summary)

Sarr, P. S., T. Yamakawa, S. Fujimoto, Y. Saeki, H. T. B. Thao and A. K. Myint 2009 Phylogenetic diversity and symbiotic effectiveness of root-nodulating bacteria associated with cowpea in the south-west area of Japan. Microbes Environ., 24 105-112

Pareek, R. P, J. K. Ladha and I. Watanabe 1990 Estimating N2 fixation by Sesbania rostrata and $S$. cannabina (syn. S. aculeata) in lowland rice soil by ${ }^{15} \mathrm{~N}$ dilution method. Biol. Fert. Soils, 10: 77-88

Rees, R. M., L. Yan and M. Ferguson 1993 The release and plant uptake of nitrogen from some plant and animal manures. Biol. Fertil. Soils, 15: 285-293

Rinaudo, G., D. Alazard and A. Moudiongui 1988 Stem nodulating legumes as green manures for rice in West Africa. In Sustainable Agriculture. Green Manure in Rice Farming. pp. 97-109. International Rice Research Institute, Manila, Philippines

Shrestha, R. K. and J. K. Ladha 1998 Nitrate in groundwater and integration of nitrogen-catch crop in rice-sweet pepper cropping system. Soil Sci. Soc. Am. J., 62: 1610-1619

Singh, Y., B. Singh, O. P. Meelu and M. S. Maskina 1990 Nitrogen equivalence of green manure of wet land rice on coarse textural soils. International Rice Research Newsletter, 15: 23

Singh, Y., C. S. Khind and B. Singh 1991 Efficient management of leguminous green manures in wetland rice. Adv. Agron., 45: $135-189$

Yoshida, S. and M. Kitou 1995 Difference in phosphorus response among tropical green manure legumes grown under limed and unlimed soil conditions. Soil Sci. Plant Nutr., 41: 9-19 